\section{Post-Oslo Palestinian (un)employment: a gender, class, and age-cohort analysis}

\section{Jennifer C. Olmsted}

$\mathrm{T}$

he Palestinian economy has been devastated since 2000 , in large part as a result of the decision by the Israeli government to sever economic ties with the West Bank and Gaza Strip. Unemployment has skyrocketed, poverty has doubled, and if it were not for the influx of foreign aid, the situation would have been even more dire. ${ }^{1}$ Much of the focus in the literature has been on examining the causes and consequences of the loss of employment opportunities for Palestinian men. This article explores how changes in Israeli, Palestinian, and U.S. policy have affected women's, as well as men's, employment patterns; it also discusses class and age differences in employment.

\section{Pre-Oslo economic dependency}

Prior to the 1993 Oslo Accords, Palestinian men were quite dependent on work in Israel. Most worked in the construction, service, and agricultural sectors. In 1973, just seven years after the Israeli occupation, over 30 percent of Palestinian workers were working in Israel. That figure continued to rise, averaging between 35 and 40 percent for most of the 1980s and into 1991. Gaza in particular was highly dependent on work in Israel, with close to half of all Gazans working in Israel in the mid-1980s. Most likely to "commute" to Israel were young and relatively uneducated men from rural communities or the Gaza Strip. Although detailed and systemic statistics separated by sex, class, and community are not available for the entire time period, data for 1975 , 1977, and 1981 suggest that during this period 97 percent or more of the workers were male. Data collected in 1991 in the Bethlehem area suggested that about 2 percent of Bethlehem area women were commuting to Israel, while a survey conducted by the Norwegian organization FAFO the following year, which covered the entire West Bank and Gaza, found similar results, with about 98 percent of the commuters to Israel being male. ${ }^{2}$

As I have argued elsewhere, while men were far more visibly linked to the Israeli economy, a small, but substantial number of women also depended on Israeli capital for their livelihoods. But women's dependency on Israeli capital was less obvious because their labor force participation rates were far lower (12 versus 60 percent) and because many of these workers were engaged in home-based or small factory manufacturing employment such as apparel production. A study of the Bethlehem area for 1991 suggests that 25 percent of both male and female workers were dependent on Israeli capital, although much higher for men in terms of raw numbers given their far higher labor force participation rate. ${ }^{3}$

Post-Oslo economic and

employment crisis

Unfortunately for the Palestinians, two employment "release valves," that had previously helped ease unemployment pressures in the West Bank and Gaza, were turned

off at around the same time. Following the 1991 Gulf War, which itself was quickly followed by the Oslo Accords, when optimism about the economic and political future of the Palestinians was at its peak, Israel began reducing Palestinian access to Israel. At the same time the Gulf states reduced considerably the number of Palestinians allowed to enter. Initially this did not seem like a huge problem, because at the same time the Palestinians were beginning to form a state apparatus so that for the first time employment was being generated internally by a public sector (although there had in earlier periods been a quasi-public sector, in the form of employment in the United Nations and Israeli-run schools and other publicly provided services.) Policymakers were also enthusiastic about the idea of setting up Free Trade Zones (FTZs) to entice foreign capital. Instead, economic conditions worsened considerably following the Oslo Accords as investors were unwilling to invest in such a volatile region and as mobility restrictions placed on Palestinians by the Israeli military reduced their ability not only to participate in the Israeli economy, but also for the local economy to function effectively. ${ }^{4}$

Labor force participation rates of both men and women began to drop in the post-Oslo period and unemployment increased. This was a result of a shift in the quantity and types of employment available. Changes in the composition of the labor force also occurred. The participation rate of younger men dropped, while older men became more likely to work. Participation rates among women also changed, with highly educated women being increasingly likely to work. Among the less educated, labor force participation either stagnated or declined, and participation in wage labor in particular went down. These trends can be explained by a combination of Israeli, Palestinian, and U.S. policies.

Israeli policy was one of the largest contributors to this shift. The closing off of jobs inside Israel, while it began in the early 1990 s, continued throughout the decade so that by the year 2003 only 12 percent of workers were obtaining employment in either Israel or the settlements. ${ }^{5}$ Gazans in particular were barred, as well as most young, single men. By 2000, Gazan employment in Israel had dropped from 40 to 15 percent, while the West Bank decline was far less precipitous, falling from a high of 30 to about 20 percent. Palestinian Central Bureau of Statistics (PCBS) data from 
1995 suggest that women represented just over 3 percent of all commuters in 1995 . Most were concentrated in agriculture, while men relied more on the construction and retail sectors. The biggest losses for men were in the construction sector. Whereas in 199526 percent of men relied on this sector for work, by 2003 that figure had dropped to 19 percent. $^{6}$

At the same time, gender and age-cohort access to these jobs changed. Israel began to restrict access by younger men, particularly unmarried ones, who wanted to work in Israel. As a result a shift in the age cohort working for Israeli capital occurred. Between 1995 and 2003 the number of workers over the age of 35 working in Israel rose. In 1995 only 19 percent of those working in Israel were in the 35-45 category, while by 200328 percent were. Men aged 15 to 34, meanwhile, saw drops of about 6 percentage points during this period. Although not completely curtailed, the ease with which young men were able to obtain positions working for Israeli capital was clearly diminished and as a result there was a substantial increase in unemployment among men between the ages 15 and 25 during this period. In 2003 young men had an unemployment rate of 36.9 percent, compared to a rate for all men that, although at 27.1 percent still shockingly high, was considerably lower. ${ }^{7}$ In 1995 the unemployment rate for young men was more than ten percentage points lower -23.7 percent - which, although higher than the overall male unemployment rate of 18.5 percent, was not as far out of line with the overall rate as it was in 2003. And as pointed out by the ILO, these estimates do not include discouraged workers, that is, the many young people, both men and women, who are neither working, seeking work, or studying.

\section{Women's employment}

Women's labor force participation is often of concern to policymakers who argue that women's access to employment can increase their power within the household. While such an assumption is somewhat oversimplified, it is nonetheless important to look at women's access to employment as one measure of empowerment. The available numbers suggest that while Palestinian women's participation has fluctuated slightly, in recent years it has remained fairly stagnant, counter to trends in other parts of the world. However, examination of the data also suggest that women's access to paid employment may be declining despite a small rise in overall participation.

In 1992 FAFO estimated that women's participation was about 14 percent. It was considerably higher in the West Bank, where it was 19 percent, than in Gaza, where it was only 6 percent. In contrast, the first PCBS estimates of female labor force participation, for 1995-1997, were in the range of only 11 to 12 percent. This does not necessarily mean that women's labor force participation declined between 1992 and 1997. Instead, the higher FAFO numbers may have resulted from including more types of informal and easily missed income-generating labor performed in the home by women. Still, some change did perhaps take place between these years as the rate estimated by PCBS for Gaza is somewhat higher ( 8 percent) and the West Bank rate somewhat lower ( 17 percent) than in the FAFO study. ${ }^{8}$

Since the PCBS began conducting regular standardized labor force surveys in 1995 , it has become easier to compare figures. The overall labor force participation rate for women age 16 or older was

11 percent in both 1995 and 2003. During this time, the participation rate of West Bank women declined from 12.6 to 12 percent while that of women in the Gaza Strip rose from 7.3 to 8.5 percent. Thus women's overall labor force participation rate has remained basically unchanged, despite, or perhaps, because the region went through a period of extreme economic hardship during the period between 2000 and $2003 .{ }^{9}$

Economic theory is ambiguous on how economic hardship is likely to affect women's employment. On the one hand, increased poverty may push women into the labor market. On the other hand, increased competition for the few available jobs may lead to women being pushed out of paid employment. In the Palestinian case, it seems pretty clear that economic hardship has reduced women's access to paid employment This can be seen both by examining Palestinian data and by comparing it to data from neighboring countries. In Jordan, for example, a country with a similar population in terms of education and cultural norms, women's labor force participation began at a higher level, about 19 percent in 1990 , and rose to 23 percent by 2000 . Palestinian women's labor force participation is in fact one of the lowest in the Middle East, which, given that participation rates are low in the region, also suggests that it may be one of the lowest globally. ${ }^{10}$

A closer examination of women's participation in various sectors also suggests that the types of employment women were engaged in changed considerably between 1995 and 2003. Except for agriculture, women's participation in almost all other sectors declined. This suggests that while overall participation rates have held steady, in recent years there has been a return to working in subsistence agriculture and thus a decline in paid employment. The change in women's representation in the agricultural sector is striking, as are their relative losses in other sectors. In 1995 only 27 percent of women's employment was agricultural, but by 2003 fully half of all female employment was in agriculture. ${ }^{11}$ These numbers are even starker for Gaza, where in 1995 only 18 percent of women are recorded as being in agriculture, but by 2003 that number had risen to 53 percent.

Noteworthy also is that in 199590 percent of women in agriculture are either categorized as self-employed or unpaid family members; by 2003 that number had risen to almost 100 percent. The rise in the relative importance of agricultural work and, within this sector, the disappearance of paid positions for women, suggests that 
women's direct access to wage employment has declined precipitously in recent years and that the relatively stable female labor force participation rate masks a decline in the percentage of women in paid work, both inside and outside the agricultural sector. This is certainly in evidence in Gaza, where, in 1995, 62 percent of women workers were recorded as being wage workers and 15 percent as self-employed, but by 2003 only 41 percent were listed as wage workers and 5 percent as self-employed. Instead, the majority of women were now categorized as unpaid family labor (rising from 24 to 55 percent). In the West Bank, the ratio of unpaid to paid work stayed fairly stable during the period (40 and 60 percent, respectively), but which women were working, and where they worked, changed.

It is difficult to determine how much control women in agriculture - and in other sectors where they are primarily listed as unpaid workers, such as in the retail trade sector - have over the income that flows into the family. What may be assumed is that the working class in particular, in Gaza and in the West Bank, appear to have experienced reductions in access to direct income. Women's labor force participation patterns also changed by different amounts in different areas. For example, in examining recent female labor participation trends in the Bethlehem area, one sees that while up until 1999 this area had one of the highest labor force participation rates among women, at 22.7 percent, this plummeted to 15.5 percent in 2003 . As a result, Bethlehem went from having the highest participation rate to having one of the lowest. $^{12}$

Sectoral changes in women's employment patterns

Why has women's labor force participation stagnated and, in particular, who has found it more difficult to find paid employment in recent years? First, changes in labor demand have occurred and, second, given that men are facing very high unemployment rates, this has put pressure on labor supply and no doubt made it more difficult for women to compete. Declines in women's position have been seen in two areas that are often categorized as traditional employment areas for women, manufacturing and the health sector. Losses in the manufacturing sector occurred primarily in textiles and apparel, with the importance of that sector for women's employment being cut almost in half, from 14 to 8 percent. Again, differences between the West Bank and Gaza are noteworthy. In the West Bank about 14 percent of working women were employed in textiles and apparel, but that number had dropped to 7 percent by 2003. In Gaza the drop is much more stark. The size of the textiles/apparel industry there was slightly more important for women's employment in 1995, making up about 17 percent of women's employment, but by 2003 almost all these jobs had disappeared and less than 2 percent of women were working in textiles and apparel. This meant that less skilled, working-class women in Gaza in particular had fewer opportunities for participating in wage employment.

One contributor to this change was that when Israel negotiated the Oslo Accords with the Palestinians, it also negotiated with Jordan and Egypt. U.S. trade negotiators decided to reward Egypt and Jordan for their participation in the peace process by allowing them to export goods to the United States duty free if a certain portion of the product was produced in Israel. As a result, Jordan, which was the first to be awarded this trade status, saw an increase in exports to the United States from \$2 million in 1999 to $\$ 567$ million in 2003. Much of that trade was in the textiles and apparel sectors and employed migrant workers from Bangladesh and China. ${ }^{13}$ Thus, the peace agreement that the United States brokered likely played a direct role in reducing employment opportunities for W est Bank and Gaza Palestinians, a problematic result given the crisis of high unemployment in the territories. In particular, poor, less educated Palestinian women and men lost out to workers in Jordan, with the added irony being that many of these were not Jordanians (or Palestinians living in Jordan) but instead were migrant workers coming from elsewhere.

The reduction in the health care sector was not quite as severe, dropping from 10 to 5 percent of women's total employment. While men have not replaced women in the textiles and apparel industry — those jobs have disappeared — they do appear to be increasingly entering the field of health care and social work: this sector made up 7 percent of all male employment in 2003, up from 2 percent in 1995. More striking, about 50 percent of employees in this category were women in 1995, but now only 14 percent are. Thus another result of the economic hardship currently being experienced is that work that is often seen as "women's work" appears to be attracting men, and a defeminization of the health sector has been occurring.

The only two sectors that have experienced employment growth between 1995 and 2003 are the public sector and the transportation sector. The latter is male dominated and has not led to increased employment for women. In contrast, the public sector has been one area where opportunities have been created for women. With the establishment of the Palestinian National Authority (PNA), the creation of a number of government offices has led to a substantial expansion of the public sector. In 1995/96, 17 percent of working women and 8 percent of working men were identified as government employees, and by 2003 those percentages had risen to 23 and 14 percent, respectively. In Gaza, male reliance on the government sector was 19 percent in 2003, almost has high as for women.

While the public sector is thus one area where women have seen opportunities expanding, only highly educated women are generally eligible for employment in this sector. Almost all of the workers in the public sector were identified as being in one of three subsectors - administration and security, education, and health and social work - all of which require fairly high levels of education. As a result, the average number of years of education among female public sector employees was 13.9 in 1995 and 14.5 in 2003. Among men, the average years of education was also fairly high, beginning at 11.8 and rising to 12.6 , for the same years. The mean level of education among those surveyed did not change between 1995 and 2003 and stayed at just below nine years of education. 
Put another way, over 90 percent of all women working in the public sector have the equivalent of a high school degree or higher. And, for 2003, 87 percent of female PNA employees possessed the equivalent of a post-high school degree education (14+ years), and of those the majority had a B A-equivalent or higher. While still biased in favor of educated Palestinians, in 2003 only 49.3 percent of men had a post-high school degree and about one-third had less than a high school degree. The stimulation of government spending has no doubt helped the entire economy, but the actual employment options have not necessarily gone to less skilled Palestinians, who lost jobs inside Israel, but instead to those with more education. Thus while the jobs that the government has created for women are mostly going to educated women, those who had lost jobs were often less skilled women in the manufacturing sector. And while the Palestinian security forces have expanded considerably and have provided employment for some less educated men, no similar outlet is available for women.

\section{Conclusion}

Recent data collected by the PCBS suggest a number important changes in the structure of the Palestinian labor market. First, there has been a small decline in male labor force participation and very little change in the labor force participation rate among women. This alone is cause for concern because it indicates a high level of discouragement among Palestinian workers. But these numbers mask a more complex picture: employment options have changed for individuals, depending on their class, sex, and age. Less educated women experienced a decline in their access to paid employment; participation rates among more educated women have risen. And especially in Gaza a large increase in the number of women working in the unpaid agricultural sector can be seen that parallels a drop in women's access to wage labor. This indicates that the economy is regressing. Among men shifts have occurred as well, with younger men experiencing a very large increase in unemployment.

These trends can be explained by a combination of Israeli, Palestinian, and U.S. policies that have shifted labor demand and put increasing pressure on labor supply, causing less educated women (as well as some less educated men) in particular to lose out. The Israeli government has increasingly isolated the Palestinian economy, reducing employment options for workers. U.S. policies that have encouraged joint ventures between Jordanian (and more recently Egyptian) firms, have done so at the expense of Palestinian workers who had in the earlier period provided a cheap manufacturing labor force for Israeli capital. This is particularly the case for less educated women, many of whom depended on the textile and apparel industry, working as subcontracted workers for Israeli firms. While this work was certainly exploitative, at least it provided less educated women with their own income source Palestinian policies, while they have stimulated the economy by enlarging the size of the public sector, have mostly created jobs for more educated Palestinians, particularly for women. It is also clear that this type of public sector employment is not sustainable in the long run.

The patterns being observed suggest cause for serious concern. They indicate that in the post-Oslo period, the most economically disadvantaged are less educated men and women who are also likely to have been poor and economically vulnerable even before these policy changes went into effect. In fact, the World Bank estimates that poverty rates in the Palestinian territories rose from 25 to 60 period during this period. Thus these patterns can be seen as a basic human rights issue, a gender rights issue, and probably also as a large contributing factor to the political instability in the Palestinian territories. A short-term policy solution to this problem is more targeted employment creation, but a parallel requirement is to address the way Israeli policies in particular continue to cripple the Palestinian economy and the need to find a way of guaranteeing Palestinian economic sovereignty.

\section{Notes}

Jennifer C. Olmsted is an associate professor of economics professor at Drew University in Madison, NJ. She can be reached at jolmsted@drew.edu. Funding for this research was provided by the Economic Research Forum (ERF) and the Palestinian American Research Center (PARC).

1. See World Bank (2001; 2002; 2003; 2004), UN (2002), and ILO (2005) for discussions of rising poverty and aid dependency. Data suggest that the Palestinians have had one of the highest per capita dependencies on foreign aid globally in recent years.

2. FAFO has carried out numerous surveys in the Arab world and elsewhere. See http://www.fafo.no/english/hist/abo-Fafo.html for more information. For discussions of Palestinian employment in Israel, see, e.g., Semyonov and Lewin-Epstein (1987), Heiberg and Ovensen (1993), Olmsted (1994), Freeman, Abu-Shoker, El-Ahmad, and Klinov (1995), Roy (2001), Sayre (2001), and Farsakh (2002; 2005).

3. See Olmsted (2001) and Hammami (2001) for discussions of how Palestinian employment patterns were gendered in the pre-Oslo period

4. For a critical discussion of the economic protocol of the Oslo Accords, see Olmsted (1996), Farsakh (2001). Numerous reports and articles have documented how Israeli closure policies have crippled the Palestinian economy, e.g., World Bank (2002; 2003; 2004), UN (2002), Ruppert Bulmer (2003), ILO (2005).

5. Although 1992 was the peak year for Palestinian migration, it was already clear in 1991 that Israel was beginning to reduce access to Israeli employment by tightening the work permit system and setting up road blocks to monitor and control Palestinian 


\section{movements.}

6. See Farsakh $(2002 ; 2005)$ for a discussion of trends in Gaza and the West Bank. PCBS began collecting data in 1995. This section relies heavily on the 1995/6 and 2003 labor force surveys collected by the PCBS.

7. Author's estimates using PCBS data. Online ILO estimates for 2003 suggest a marginally lower rate of 26.7 percent (http://laborsta.ilo.org/). Unemployment data for 1995 were unavailable at the ILO web site. Note that the unemployment rate suffered by Palestinians men in 2002 was even higher at 33.5 percent. ILO estimates are notoriously low because they define anyone who has worked during the reference period as employed. Underemployment is a serious problem among Palestinians; many work as day laborers and do not know from one day to the next whether they will be employed.

8. For a summary of the FAFO findings, see Heiberg and Ovensen (1993). Subsequently, PCBS (1998) released a report with various statistics on men and women.

9. ILO data suggest that female labor force participation may have risen somewhat between 2001 and 2004 (data for 1995 and 2003 were not available) from 10.4 to 13.5 percent. See http://laborsta.ilo.org/. Published PCBS data differ somewhat from the numbers calculated here, suggesting a small rise in women's labor force participation between 1995 and 2000, from 11 to 12.7 percent, and a leveling off in 2003 at 12.8 percent. See http://pcbs.gov.ps/.

10. Statistics on Jordanian women's employment patterns are in World Bank (n/d). For a critical discussion of women's employment throughout the region, see Olmsted (2005).

11. Although considerably less pronounced, there is also evidence that men's participation in unpaid agricultural work has increased as well.

12. For more discussion of some of the unique challenges facing Bethlehem, see UN (2004).

13. See W ahash (2004); Greenhouse and Barbaro (2006). The Egyptian agreement did not come into effect until 2004, but the Jordanian agreement has been in effect since the late $1990 \mathrm{~s}$.

\section{References}

Farsakh, L. 2000. "Under Siege: Closure, Separation and the Palestinian Economy." Middle East Report 217. Winter. http://www.merip.org/mer/mer217/ 217 farsakh.html [accessed 22 June 2004].

Farsakh, L. 2002. "Palestinian Labor Flows to the Israeli Economy: A Finished Story?" Journal of Palestine Studies, Vol. 32, No. 1, Issue 125, pp. 13-27.

Farsakh, L. 2005. Palestinian Labor Migration to Israel: Labor, Land and Occupation. London: Routledge.

Freeman, R., A. Abu-Shokor, A.Q. El-Ahmad, and R. Klinov. 1994. "Palestinian-Israeli- Jordanian Labour Mobility: The Current Situation and Issues for a Peaceful Future," pp. 69-92 in S. Fischer, et al. Securing Peace in the Middle East. Cambridge, MA: The MIT Press.

Greenhouse, S. and M. Barbaro. 2006. "An Ugly Side of Free Trade: Sweatshops in Jordan.” The New York Times. 3 May 2006, pp. C1, C7.

Hammami, R. 2001. "Gender Segmentation in the West Bank and Gaza Strip: Explaining the Absence of Palestinian W omen from the Formal Labor Force," pp 175-204 in E.M. Cinar, ed. The Economics of Women and Work in the Middle East and North Africa, vol. 4 of Research in Middle East Economics. JAI/Elsevier: Amsterdam.

Heiberg, M. and G. Ovensen. 1993. "Palestinian Society in Gaza, West Bank and Arab Jerusalem: A Survey of Living Conditions." FAFO Report 151, Oslo.

[ILO] International Labor Organization. 2005. "The Situation of Workers of the Occupied Arab Territories.” International Labour Conference 92nd Session, 2004. Report of the Director-General. Geneva: ILO. http://www.ilo.org/wcmsp5/ groups/public/---dgreports/---dcomm/documents/meetingdocument/kd00009.pdf [accessed 21 May 2008].

[ILO] International Labor Organization. n/d. LaborSta Internet. An Online Source for Labor Data. http://laborsta.ilo.org/ [accessed 21 May 2008].

Olmsted, J. 1994. "Education and Migration among Bethlehem Area Palestinians." PhD dissertation. Department of Economics. Davis, CA: University of California, Davis.

Olmsted, J. 1996. "Thwarting Palestinian Development," Middle East Report. No. 201, Vol. 26, No. 4 (Fall), pp. 11-13, 18

Olmsted, J. 2001. "Men's Work/Women's Work: Employment, Wages and Occupational Segregation in Bethlehem," pp. 151-174 in E.M. Cinar, ed. The Economics of Women and Work in the Middle East and North Africa, vol. 4 of Research in Middle East Economics. JAI/Elsevier: Amsterdam.

Olmsted, J. 2005. "Is Paid Work The (Only) Answer? Women's Well-Being, Neoliberalism and the Social Contract in Southwest Asia and North Africa." Journal of Middle East Women's Studies, Vol. 2, No. 1, pp. 112-139.

[PCBS] Palestinian Central Bureau of Statistics. 1998. "W omen and Men in Palestine 
Trends and Statistics." Ramallah, Palestine: PCBS.

Roy, S. 2001. Gaza Strip: the Political Economy of De-Development. Washington, D.C.: Institute of Palestine Studies.

Ruppert Bulmer, E. 2003. "The Impact of Israeli Border Policy on the Palestinian Labor Market." Economic Development and Cultural Change, Vol. 51, No, 3, pp. 657-676.

Sayre, E. 2001. "Labor Demand and the Wage Gap: Evidence from the West Bank and Gaza Strip." Contemporary Economic Policy, Vol. 19, No. 2, pp. 213-224.

Semyonov, M. and N. Lewin-Epstein. 1987. Hewers of Wood and Drawers of Water: Noncitizen Arabs in the Israeli Labor Market. New York: Cornell University Press.

[UNSCO] United Nations Special Co-ordinator. 2002. "The Impact of Closure and Other Mobility Restrictions on Palestinian Productive Activities." October. http://www.un.org/News/dh/mideast/econ-report-final.pdf [accessed 22 June 2004].

[UN] United Nations. 2004. "Costs of Conflict: The Changing Face of Bethlehem." Joint publication of the Office for the Coordination of Humanitarian Affairs (OCHA) and the Office of the Special Coordinator for the Peace Process in the Middle East (UNSCO). New York: United Nations. http://domino.un.org/pdfs/Beth_Rep_Dec04.pdf [accessed 21 May 2008].

Wahish, N. 2004. "Enter QIZ." Al-Ahram Weekly Online. Issue No. 721, 16-22 December 2004. http://weekly.ahram.org.eg/2004/721/ec1.htm [accessed 21 May 2008].

World Bank. n/d. Genderstats. http://devdata.worldbank.org/genderstats/ genderRpt.asp?rpt=profile \&cty=JOR,Jordan\& $\mathrm{hm}=$ home [accessed 21 May 2008].

World Bank. 2001. "Poverty in the West Bank and Gaza." Washington, D.C.: World Bank. http://nweb18.worldbank.org/mna/mena.nsf/Countries/West+Bank/ 67FB14AF1F54168785256B85003C5F07?OpenDocument [accessed 22 June 2004]

World Bank. 2002. "Fifteen Months - Intifada, Closures and Palestinian Economic Crisis: An Assessment." March. Washington, D.C.: World Bank. http://lnweb1 8.worldbank.org/mna/mena.nsf/Countries/West+Bank/67FB14AF 1F54168785256B85003C5F07?OpenDocument [accessed 22 June 2004].

World Bank. 2003. "W orld Bank Report on Impact of Intifada: West Bank and Gaza Update." April-June. West Bank and Gaza Update. The World Bank Group. A Quarterly Publication of the West Bank and Gaza Office. See http://www-wds. worldbank.org/servlet/WDSContentServer/WDSP/IB/2003/07/14/000160016 20030714153748/Rendered/PDF/263131 W BG0update 1 April1 June02003.pdf [accessed 21 May 2008].

World Bank. 2004. "Four Years — Intifada, Closures and Palestinian Economic Crisis An Assessment." http://siteresources.worldbank.org/INTWESTBANK GAZA/Resources/wbgaza-4yrassessment.pdf [accessed 21 May 2008]. 